\title{
Why are women dying in India's sterilisation camps?
}

\author{
(C) $(\mathbb{O} \Theta$ OPEN ACCESS
}

Far from offering suitable birth control methods to men and women at different points in their lives, India's programme focuses on female tubectomy carried out in substandard camps, Priyanka Pulla reports

\section{Priyanka Pulla journalist, Bangalore and Hyderabad, India}

Two weeks after 13 women died after surgical sterilisation at a camp in the central Indian state of Chhattisgarh, the cause of their deaths remains unknown. ${ }^{1}$ Laboratory reports have confirmed the presence of toxins in the drugs given to these women. ${ }^{2}$ However, the postmortem examinations of seven of the women indicate they had septicaemia, which can result from poor hygiene during surgery, according to a fact finding mission by the non-governmental organisations Population Foundation of India, Parivar Seva Sansthan, the Family Planning Association of India, and Common Health. ${ }^{3}$

Aside from the drugs, septicaemia alone "would have been enough to risk killing every woman," said Poonam Muttreja, executive director of Population Foundation of India and part of the mission.

\section{Judicial investigation}

A judicial committee will present a report to the government in three months' time. R K Bhange, chief medical and health officer of Bilaspur, the district where the camp was held, has been suspended. He had ordered the procurement of the drugs from a local manufacturer without examining quality certificates, said Rajat Kumar, a public relations official from the Chhattisgarh government.

The drug procurement procedure wasn't the only thing that had gone wrong at the camp. Rules were flouted at several levels. The camp was held in an abandoned hospital with no running water and sterilisation of rusty equipment was inadequate.

"Everything that could have been done wrong was done wrong," Muttreja said.

These dangerous conditions are not uncommon in sterilisation camps throughout India, claim women's health activists. They say that such camps, favoured by the Indian government as a way to perform tubectomies on many women in one go, often exceed the prescribed limit for surgeries in a day, do not adequately sterilise the equipment used on patients, and do not provide counselling before operations or care afterwards.
"This was waiting to happen," Abhijit Das, a public health researcher at Delhi's Centre for Health and Social Justice, told The BMJ. "We are continuing to pursue this mass sterilisation approach with extremely poor quality and absence of oversight."

\section{Quality assurance committees}

Concerns about the way sterilisation camps are run have arisen several times in the past decade. In 2006, in response to a public interest litigation that listed the deficiencies in the camps, the Supreme Court of India issued guidelines for conducting mass tubectomies. ${ }^{4}$ Under these guidelines, states were asked to set up a panel of approved doctors to operate in the camps; to provide counselling to women and insurance if something went wrong; and to ensure informed consent.

Not much has changed since. The quality assurance committees that were set up in every district to oversee sterilisation camps have not been doing their jobs, said Das. "These committees hardly meet. So, on paper, there is a lot of progressive language, there is a procedure, but nobody checks if the procedures are in place," he explained.

Ayyaj Fakirbhai Tamboli, the mission director of Chhattisgarh's National Rural Health Mission, which funds sterilisation camps, agrees that quality assurance committees aren't doing enough. He says these committees have been focusing too much on infrastructure without paying heed to standard operating procedures. "There is a lacuna in their training. Quality is considered more of an infrastructure issue rather than a standard operating procedure issue," he told The BMJ.

But infrastructure at the Chhattisgarh camp where the women died was not adequate either. Sterilisations were carried out at a breakneck pace, with surgeon R K Gupta performing 83 operations in a few hours, well beyond the maximum limit of 30 allowed for each surgeon in a day. Gupta told the media outlet Bloomberg that he had carried out so many operations because too many women had turned up at the camp and he had no choice but to operate on them. ${ }^{5}$ 


\section{Government female sterilisation targets}

Health rights non-governmental organisations allege that the large number of women seeking sterilisation is the direct result of sterilisation targets pursued by the Indian government. Even though the government announced a "target-free" approach to population control in 1996, accredited social health activists - community workers under India's National Rural Health Mission - continue to receive sterilisation targets from their superiors.

\section{"Sterilisation targets are a hidden agenda of the Indian} government," said Nibedita Phukan, a researcher at the Centre for Health and Social Justice. During surveys carried out by the centre, community health workers and medical health officers said that they were asked to bring a fixed number of women to sterilisation camps. If they couldn't meet their targets they received warnings and pay cuts. To help meet these targets, women were also paid up to Rs1000 (£10; €13; \$16) each for being sterilised.

This is perhaps why female sterilisation forms a disproportionately large part of India's population control strategy, with five million women having the procedure each year. Even though the government of India talks about a "cafeteria" approach to contraception, whereby women can choose the method most suited to them, sterilisations outshine temporary methods such as birth control pills and condoms or male methods such as vasectomy. The Chhattisgarh government alone has planned for 150000 female sterilisations this year, while its estimate for vasectomies is only $8000 .{ }^{6}$ There is no estimate for the number of people who will receive contraceptives such as birth control pills and condoms.

Tamboli says this skew exists for multiple reasons. The first is a distribution problem. Condoms and birth control pills need to be used on a regular basis, but the current government supply chain is unable to assure this. Primary healthcare centres often run out of supplies, leaving women who have opted for contraceptive pills or condoms in the lurch. As for the low number of vasectomies carried out, Tamboli calls this is a "sociological problem." "We do not deny vasectomies to anyone. But men are simply not coming forward," he said.

\section{Permanent and irreversible}

The focus on female sterilisation is troubling, says Suchitra Pandit, the president of the Federation of Obstetrics and Gynaecological Societies of India. It is a permanent and irreversible procedure, which means young women who may change their minds later are left with little choice. And like any surgical procedure, tubectomy carries the risk of complications. Ectopic pregnancies, where an embryo gets implanted outside the uterus, can also occur in some cases. A few studies indicate that tubectomies can increase the risk of abnormal uterine bleeding. Overall, tubectomies fail in one out of every 200 cases, ${ }^{7}$ with the risk of failure increasing with every year after the procedure. This is something women should be warned about before they are sterilised so that they can seek immediate medical help, Pandit says. "Either the patient must be counselled very well if she undergoes sterilisation or you have to give her access to other methods."

Sterilisation camps often fail to provide either counselling or aftercare. In a 2009 survey of 17 sterilisation camps carried out by the Centre for Health and Social Justice, only nine were found to offer counselling, ${ }^{8}$ and only $17 \%$ of the 160 women interviewed had been informed of contraceptive options other than sterilisation.

According to Das, accredited social health activists (ASHAs) often ignore the contraception needs of women who merely want to space out their children, instead focusing on tubectomies. "The ASHA doesn't know about temporary methods and doesn't get into action until a woman has two children. On paper, they talk of contraception, life skills, and education, but all that isn't happening. This entire programme is geared at people who have two children or more," said Das. While the camps in the 2009 study did better in terms of postoperative care, this isn't the case everywhere in India. Last year, a hospital in the Malda district of West Bengal dumped the unconscious bodies of 100 women who had had sterilisation into a field because the hospital did not have enough space for them. ${ }^{9}$

\section{Time to end the camps?}

It may be difficult to bring down the rates of female sterilisation immediately, but Pandit and public health groups Sama and the Centre for Health and Social Justice say that it is time to end sterilisation camps. Such camps inevitably end up having targets and flout guidelines to try to meet them. It is far better to bring women to hospitals, where they can have thorough preoperative screening and be turned down if they do not meet the criteria, something that rarely happens at camps.

"We are saying: why do doctors have to go into some peripheral area where there is no proper lighting, no proper set up, and they don't know who the paramedical person helping them out is? Why don't you just get the patients to the hospital?" asked Pandit.

Competing interests: I have read and understood BMJ policy on declaration of interests and have no relevant interests to declare. Provenance and peer review: Commissioned; not externally peer reviewed.

Das A. India's latest sterilisation camp massacre. BMJ 2014;349:g7282.

2 Sterilization deaths: Labs confirm poisonous content in medicines, Times of India 2014 Nov 23. http://timesofindia.indiatimes.com/india/Sterilization-deaths-Labs-confirmpoisonous-content-in-medicines/articleshow/45249766.cms.

3 Multiorganisational Team. Robbed of choice and dignity: Indian women dead after mass sterilization. 2014. www.populationfoundation.in/sites/default/files/Report\%20on\% 20Bilaspur\%20Visit\%202\%20december\%202014.pdf.

4 Supreme Court of India. Laws (SC)-2005-3-159. 2005. www.the-laws.com/encyclopedia/ browse/ShowCase. aspx? Caseld=005002073100.

5 Mehrotra K. Arrested Indian doctor says toxic pills killed 13 women. Bloomberg 2014 Nov 12. www.bloomberg.com/news/2014-11-12/doctor-says-toxic-indian-pills-killed-womenhe-sterilized.html.

6 National Health Mission. State program implementation plans. http://nrhm.gov.in/nrhmin-state/state-program-implementation-plans-pips/chhattisgarh.html.

7 Date SV, Rokade J, Mule V, Dandapannavar S. Female sterilization failure: review over a decade and its clinicopathological correlation. Int J Appl Basic Med Res 2014;4:81-5.

8 Centre for Health and Social Justice. Reaching the unreached. 2009. www.chsj.org/ uploads/1/0/2/1/10215849/reaching_the_unreached.pdf.

9 Women dumped in field after sterilization in West Bengal. LiveMint 2013 Feb 7. www. livemint.com/Politics/3C0ykn7qH3ADohvXYz7G4O/Women-dumped-in-field-aftersterilization-in-West-Bengal.html?ref=also_read.

\section{Cite this as: BMJ 2014;349:g7509}

This is an Open Access article distributed in accordance with the Creative Commons Attribution Non Commercial (CC BY-NC 4.0) license, which permits others to distribute, remix, adapt, build upon this work non-commercially, and license their derivative works on different terms, provided the original work is properly cited and the use is non-commercial. See: http://creativecommons.org/licenses/by-nc/4.0/. 